\title{
THE DEVELOPMENT OF HISTORICAL THINKING AND SKILLS IN THE TEACHING OF HISTORY IN THE SENIOR SECONDARY SCHOOL CURRICULUM IN INDONESIA
}

\author{
Said Hamid Hasan ${ }^{1}$
}

\begin{abstract}
The present study analyses history education as it is in curriculum document of senior secondary school. The curriculum document is a part of content standard document which is officially announced by Minister of National Education Regulation number 22 year 2005. This oficial document contains amongst others curriculum structure, competency standards and basic competency. Two major questions this study asks are (1) what is the concept of history education stipulated in curriculum document?, and (2) how far the existing curriculum provides possibilities for the development of historical thinking and skills?

The questions are answered by analysing the document. Considering the characteristic of curriculum document which is an official document and all ideas are planned strictly and clearly written, the analysis uses logical analysis approach where the two research questions serve as analysis framework. The result shows that the exisiting curriculum conceived history education as a scientific discipline education. Also, the curriculum provides an ample opportunity to develop historical thinking and skills. Design used by the curriculum is concecutive design for the development of thinking and learning skills.

It concluded that the concept of history education as a scientific discipline education is appropriate considering the objective of senior secondary education to prepare the students for university education. The study also suggests teachers of history to implement integrated design for the development of historical thinking and skills as an alternative to consecutive design.
\end{abstract}

Key words: history education concept, historical thinking and skills, substantive content, skill content, consecutive design, integrated design

\section{Introduction}

The present study is a documentary study focusing on history education as planned in the existing senior secondary school curriculum. Two major questions this study asks are (1) what is the concept of history education stipulated in

1Prof. Dr. Said Hamid Hasan, M.A; Professor of History Education, Faculty of Social Science Education, Indonesia University of Education, President of Association of History Researcher and Educator, and President of Indonesia Association of Curriculum Developers. This article has been reviewed by Prof. Dr. Helius Sjamsuddin, M.A (Indonesia University of Education), and Prof. Dr. Rochiati Wiriaatmadja, M.A (Indonesia University of Education). 
curriculum document?, and (2) how far the existing curriculum provides possibilities for the development of historical thinking and skills? As the nature of the study is documentary study, the analysis focuses on curriculum document as issued by the Central Government, not on curriculum document developed by each individual school which is called Kurikulum Tingkat Satuan Pendidikan (KTSP $=$ school-based curriculum).

The reason for focusing on the curriculum document from the central government, from now on central government will be addressed as Government, because this document plays a pivotal position or even dominant position in the development of KTSP document. In fact, it is adequate to say that the curriculum document of the Government is fully adopted by and becomes the major feature of every KTSP document including the content of history education. No school has any space to add more content to the history education as already developed by the Government. Policy on local content curriculum which should be developed by a school does not apply to any existing course in the Government curriculum document and content for history education is no exception. Local content curriculum should only be organised as course(s) separated from the designated courses. Thus, by such a policy no one school put any new content to enrich content for the existing courses from the local perspectives. This undeniable fact serves as the fundamental reason to put the Government curriculum document as the focus of the present study.

The Government curriculum document is legally and publicly announced by the Peraturan Menteri Pendidikan Nasional (Minister of National Education Regulation) ${ }^{2}$ number 22, year 2005 on Standar Isi (content standard). This document consists of two parts which are general explanation about all the courses and technical description of each individual course. The explanation part describes curriculum structures, the amount of learning time for an academic year, and academic calendar. The technical description part explains the background, objectives, scope, competencies standard, and basic competencies. The present study concerns about the technical description part because this part contains specific information about history education. In other words, information from this technical description of history course is the primary data source of the present study.

Data analysis is conducted by using dedutive or prescriptive approach. Fullan and Pomfret (1971) call this approach "pre-ordinate". This approach is normally and universally applied for a study of curriculum document, and it proves by many research of this kind as fruitful in getting the meaning and understanding of what is planned in the curriculum. By nature, curriculum document is not the same or even similar to other documents used as sources of data in qualitative research. Curriculum document is specifically and systematically designed, developed, and written to be used by specific schools. It is not an open document

2 The Peraturan Menteri Pendidikan Nasional (Minister of National Education Regulation) in this article, from now on will be addressed as Minister Regulation whenever appropriate 
and therefore data coding such as open coding, axial coding or selective coding (Borgati, Ratcliff, Miles and Hubermann) are not suitable for data analysis of the present study.

By this approach, a researcher uses theme or ideas as a framework to analysize the content of curriculum document. Examples of this approach are studies by Tanriverdi and Apak (2010), and Mrdalj and Jovanovic (2003). Tanriverdi and Apak analysed the idea of Media Literacy Education in primary school curriculum in Turkey, Ireland, and Finland analysed the curriculum document for the idea of Media Literacy Document. Mrdalj and Jonavovic analysed the idea of Classical Structural Design and Unified Modeling Language in Computer Information System curriculum. In the present study, the research questions guide the researcher to deeply scrutinise every detail information from the document back and forth to get the understanding. This part of analysis answers the question of the concept of history eduction. Further analysis is then conducted by comparing what is planned in the curriculum document and theoretical framework on the development of historical thinking and skills. To do this analysis some discussions on the development of syllabus is necessary because it give insight on the way the historical thinking and skills is and should be developed. The result of this analysis answers the question of possibilities the curriculum provides for the development of historical thinking and skills.

\section{Historical Thinking and Skills Content}

Historical thinking and skills are curriculum contents which should be learned and mastered by students. Sometimes these kinds of content are called intellectual content, other contents of these kinds are called habitual skills. It is intellectual skills because they require students to develop their cognitive capacities more than just to remember and understand but up to higher levels of cognitive skills such as to apply, analyze, evaluate and create (Anderson, et al., 2001). Intellectual contents are important but unfortunately they are inertia without knowledge or substantive content. Intellectual and other skills can only be developed when there are substance contents to process or to work with. The substance contents are knowledge of historical facts, the cause or background of the events, the process and factors affected the process, concepts to describe and explain the events, the ending of the events, and its impacts.

Knowledge serves as input materials for intellectual skills to process and develop but knowledge is also a product of the skills. Knowledge produced by the intellectual process has more values than knowledge used as an input. The magnitude and richness of the difference between knowledge as the input and the product indicate the capacity of intellectual skills to process the knowledge. The capacity is increased to a level of proficiency when the skills regularly used and each time the intellectual skills should process new and different kinds of knowledge. 


\section{Knowledge as Substantive Contents}

Theimplementation of historyeducationstillposesmanymisunderstandings amongst teachers, students, society, and even policy decision makers. One of the misundertandings is the common public opinion which says that history is an easy subject to master. If it is true that history is a $\mathrm{n}$ easy subject it would be very good because students will not get any difficulty in understanding and applying what they have learned from history lessons. This means that history education is also very useful for the lives of the students. Unfortunately, this is not the case because many studies show that students learn only to recall historical facts and the learning outcomes is unsatisfactory. Many students got lower score from teacher-made test administered after a discussion of a historical topic. In fact, many comparative study result show that score of history test on average is lower than score of mathematics and science. While it is realised that the difference in the score might be attributed by some students' factors, teaching process, and the test itself, however, the result indicates that history is unfortunately not easy for most of the students.

One thing is obvious that the contents of history teaching are very abstract. There is no single concept or fact in history contents is concrete. The concept of time and other concepts used in describing historical account are abstract. For example, the concept of time it is not easy for the students to fully understand. What is meant by the past such as a year ago, a decade ago, a century ago with the space of time it covers are not simple and easy to understand. It is also not easy to understand a period called prehistory and the way prehistoric years is calculated backwardly. But it is unfortunate that every historical account will talk about the time, period, places, actors, nation, kingdom, republic, monarchy, power, movements, revolutions, wars which are abstract, not to mention development and change as the two basic concepts of history. All of those are abstract and abstract contents can only be fully understood by abstract thinking capacities (formal thinking) and suitable educational process to develop the capacities. In other words, while the students of senior high school (age 16/17-18/19) have already reached the capacity of formal thinking does the curriculum provide ample learning opportunities to develop the formal thinking capacities? The curriculum should also provide learning experiences to address these abstract content as such that the students can use them correcly in their communication, orally or writtenly.

Another misunderstanding about history education is again related to the contents of history. The contents of history are about the past and the past is final so it is commonly perceived that what students learn has nothing to do with the present. This misunderstanding cuts off history class from everyday life of the students. This is unfortunate albeit no one denies that historical events occured in the past but historical account is what historian sees the events, put meaning including their "feelings and thoughts" (Cooper, 1992:9) about the fact, and then reconstruct them as an historical account. The past is undoubtedly the past of 
human beings and their ways to live, to organise themselves, ways to realise their ideas and objectives, values they cared and honored, and ways they deal with challenges. As the present society is a continuation of those long periods of development and changes, naturally, there should be ideas, objectives, ways to organise, ways to respond to chalenges, values and tradition which are still relevant, suitable, and inherited by the present society. This means that some of what happened in the past are still living reality in the present society (Wineburg, 2001:11). Thus, on the contrary to the misconception, what students learn from the contents of history should be able to serve as a framework for understanding and analysing the present society. In other words, though history confines to the past but history education should not be the time wall to prevent students to learn about the present society. To learn the past is to understand the present.

Historical account serves as the means to develop historical knowledge and understanding, historical thinking and skills, values, attitudes, and habit. The last three capacities, known as affective domains, are not the focus of the present study. However, history curriculum should provide learning the students with opportunities to develop them as qualities of their personality and characters. They are very valuable qualities for the students to develop and to have through a study of history. As those affective quality, historical knowledge, historical thinking skills can only be developed through historical account and resources. By studying a historical topic students developed their understanding by applying their abilities in historical thinking. Also, by studying historical resources they apply skills to collect facts, organise and analyse the facts, develop their knowledge and understandings and then reconstruct them into an historical account.

Other qualities which should be develop in history education are historical knowledge and understanding. These qualities as much as important as those historical thinking and skills. It is adequateto say that there will benoother cognitive nor affective qualities can be developed and constitute students personalities when they have knowledge of historical facts and terms. In this perspective, students should be knowledgeable about historical facts, interpretation, analysis, reconstruction, historical accounts, criiticism, bias, cause and effect, continuity and change, terms related to historical events which are basic and essential for the development of historical understanding, and subsequently is prerequisite for the development of historical thinking and skills. Thus, the developmentment of those thinking and skills requires the students to have knowledge and understandings of those historical facts and terminologies. These knowledge and understandings used by students when they read an historical account, to develop historical understandings and at the same time to apply historical thinking and skills. Those qualities can be used by studying historical evidences for a historical event, and reconstruct a historical story of their own.

The knowledge, understanding, historical thinking and skills the students learn, develop and master from history classes are potentials for the multiple uses, further study and civic lives. The problem is, in many history classes, these 
potentials are developed and directed for one single purpose only which is to pass or to get higher score from a test. Another use which is the application of the learned knowledge and skills to civic lives, everyday lives, is hardly evidence. Educationally, this one single and separated approach violates the principles of education because education aims to develop students potentialities for their future lives. To pass or get higher score from a test is also at the cost of the students because by that situation the curriculum does not function to prepare the students for their better lifes whatever social status they would earn later on. History education should provide ample opportunities for students to apply what they have learned in classroom to their everyday lives. The past should live and be character of the students to live in a society actively and productively.

Knowledge and understanding are called "mastery learning" because the students can master the content everytime they learn them. The content will reside in the "ordinary memory" (Gordon , 2003:1-2) and as he puts it "ordinary memory is conscious and relatively slow-we are often aware of the effort involved in trying to remember a name or a date". According to Gagn everything someone read, hear, or see will reside forever in the "ordinary memory". Forget is a problem to recall the knowledge which is attributed to a situation where the knowledge is unconnected with the existing schema, filed at an unidentified place or placed in bad sectors of the memory. The recall of the facts can be easily done when they are connected with what the students already have in their memories, and then a particular clue to recall the designated knowledge is always available. Particular mnemonic clue can be developed. The frequent use of the knowledge will put them always in the working memory and make them easily be retrieved.

\section{Thinking and Skills Content}

Another kind of curriculum content is intellectual skills, reading skills, learning skills, values, attitudes, and habit. This category of curriculum content is labelled as "developmental content". As the name indicates, the mastery of this category of content is not easy, requires a long period of time, reinforcement efforts, and exercises during the period of study in a school. According to Gordon (2003) this content will reside in "intelligent memory". Once this category of content is mastered then the use of them is "quick, effortless, and usually unconscious. It's responsible for almost everything we do with our senses, our minds, and our muscles".

Curriculum developers have recognised this category of contents for a long time and some efforts to deal with it have been addressed. The wellknown taxonomy of educational objectives by Bloom and his colleagues (1956) is an example of the efforts. By developing the taxonomy, Bloom and his team categorised the objectives for learning but also develops levels of cognitive ability, affective stages, and the psychomotoric level of mastery. These are skills to be developed, values to be internalized and developed as a habit and character, and the muscles training controlled and managed by cognitive and affective up to the 
levels of automatic and perfect. Recently, some scholars, Anderson and colleagues (2001) revised the cognitive domain of the work of Bloom and his colleagues and title the revision as "A Taxonomy for Learning, Teaching, and Assessing" where cognitive domain is clearly formulated as skills to remember, understand, apply, analyze, evaluate, and create. The development of mastery learning education where every student is perceived be able to master any skills when it is done according to her/his personal time, and competency-based education which are aiming the mastery of knowledge and skills up to the level of proficiency.

The nature of skill content is different from knowledge. Skill contents are developing contents which mean that the mastery of skills should take a long period of learning. For example, skill in writing might be learned in a semester, a year or even more to reach a level of proficiency. Exercise by exercise should be experienced by students starting from to know and understanding the meaning of writing and all criteria to constitute a good writing. To master the skill of reconstruction of historical account is more complicated than general wriiting and so more time is needed to be proficient in this historical skill. The more complicated the technicalities to handle and procedures to follow the more time should be provided by a curriculum for students to learn the skills.

Secondly, skills can only be mastered through studying knowledge. To learn skills needs substantive contents where to know what the skill is all about and how it works, and to do the exercise for mastering the skill. Cooper (1992:35) has the same idea when he said "these processes of historical thinking must be applied to the content specified in the programmmes of study". To take analysing as an example, students should know what is meant by analysis and to analyze, works to do in analysing such as making and defining categories, labelling the categories, classifying data and information for each category, determining the relationship amongst the categories, and making conclusions. To do the analysis students should work with more than one topic of history. All topics within a semester might be necessary to develop the basic skills of analysis depending upon the professional decision of a teacher makes on the entry behaviour of her/ his students. By this characteristic, all topics of history program in a curriculum should be used as media for the development of historical thinking and skills.

Both historical thinking and skills are skills. Both skills are interacted in a study of history, and in fact in the methodology of history both skills are intertwined but conceptually historical thinking is different from historical skills. Historical thinking skills are critical thinking, creative thinking, to analysis, to determine cause-effect, to interpret, to inference, to conclude, to use historical concepts (Cooper, 1992; California State Board of Education 2000; Wineburg, 2001; Drake and Nelson 2005; Hasan, 2008) . These thinking skills are also used by other disciplines but the application for each discipline content make them unique for the concerned discipline and history in this case. Historical skills are reading, collecting resources and evidence, collecting data, categorising data, establish time frame, and writing (Tosh, 1984; Cooper, 1992;California State 
Board of Education 2000; Wineburg, 2001; Drake and Nelson 2005; Hasan, 2008) . These skills are for historical research and used to deal with historical evidences. However, as the case of thinking skills, historical skills have also similarities to those used by other disciplines but the nature of historical subject, human activities in the past and historical evidences as the sources of information of the past activities, make them specific and technically suitable for historical inquiry.

\section{The Existing Curriculum}

In the year of 2004 the Government of Indonesia issued a new law concerning the autonomy of local government. The law was signed by President Megawati Soekarno Putri on October 15, 2004 and is called Law number 32 on Local Government. In the designated law the local government is the goverment of province, district, and city. The new law replaced the previous law which was issued in 1999 on the same subject but considered no longer suitable for the area of reformation. As the previous one, however, the law of 2004 delegates some central government's authorities to local government. Paragraph 13 of the law states some delegated governmental authorities from the central government to local government and education is one of them.

In 2003 the Indonesian government issued a new Education Law replaced the former 1989 Law. When this education law was still in the process of making, the 1999 law on local government was being reviewed and the then law of 2004 on local law was being in the process of making as well. However, there was no substantial change from the 1999 Law as far as the delegated governmental authority aspects are concerned. During the period of the making, it was decided that the new education law should be in line with the law of local government. To be in such position, the 2003 education law places the authority to manage primary and secondary education as the responsiblity of the local government. Furthermore, the 2003 education law states that the central government should issues content standard, outcomes standard, curriculum structure, and other standards related with the management of kindergarten, primary and secondary education. For the development of the curriculum, it is now the right and responsibility of a school and its committee, and by the Government Act number 19 of the year 2005 curriculum developed by a school is called Kurikulum Tingkat Satuan Pendidikan (KTSP), school-based curriculum.

To contruct the whole school-based curriculum document, a school is obliged to develop local content curriculum. It is purported that the local content will make the curriculum more relevant the needs of the immediate society a school serves. To construct the school-based curriculum, the National Standard of Education Board (BSNP) issued seven principles of curriculum development a school should follow. One of the principle is the balance between national 
interests and local needs ${ }^{3}$. The local needs are represented by the local content of the curriculum while the national interests are formulated in the structure of curriculum and legally enacted by Minister of National Education Regulation on National Content Standard. The local content is organised in an independent course(s) and a school is authorised to develop different course(s) for different semester but each of the course(s) should have discrete label and explicitly distributed in the six semesters of senior secondary school curriculum (KTSP).

The local content policy is not a new one because the policy of local content curriculum was introduced for the first time in 1984 curriculum. At that time, the curriculum was nationally developed but the school was authorised to develop the local content part. In most cases, schools would decide vernacular and traditional musics as the local content courses. This was done so as the team who developed the local contents was not trained in doing needs assessment. Naturally, it was hardly possible for them to do the assessment of the local needs and developed the needs as local content courses. As the Curriculum Centre set vernacular and traditional musics as examples for local contents then it was the easiest, legal, and the most convinent way for the schools to decide vernacular and traditional musics as their local content courses.

Based upon Minister of National Education Regulation number 22 year 2005, the senior high school curriculum structure categorises curriculum contents into five groups. These groups are religion and moral, citizenship and personality, science and technology, esthetics, and physical and sport education. In every group there is at least one course. The group of science and technology is the one which has many member-courses such as mathematics, biology, physics, chemistry, economics, geography and other academic disciplinary-based courses. History is a course within the category of science and technology. Also, as explicitly written in the doument, the objective of the science and technology category is to "master competencies at advanced level of knowledge in the field of science and technology and to cultivate the habit of critical, creative, and independent scientific thinking". It is obvious that the objective of the science and technology category implies that the curriculum of the senior high school should be based upon the philosophy of essentialism. Courses constructed upon this philosophy should be developed as the teaching of separated scientific discipline and the course should be labelled according to the formal name of the disciplines (Tanner and Tanner, 1980). In this case, history education is appropriately labelled as history not social studies or other labels. In other words, the label of history in the existing curriculum complies with the philosophy of essentialism.

For the purpose to prepare the senior high school students for furthering their studies to university, the application of essentialism and the teaching of history as a separated scientific discipline is appropriate. The senior high school

3 The other six principles are student centered, diversity an integrated, responsive to the development of science and technology, relevant to the needs of daily lives, comprehensive and continuous, and life-long education (Minister Regulation nomor 22 tahun 2005) 
curriculum should provide learning experiences for students to know and understand the basic nature and structure of history, apply some basic skills and ways of thinking of history as a discipline. The only problem with this separated scientific disciplinary approach is that all the courses are compulsory for all students while it is very obvious that the number of students who do not continue their education to tertiary level is more than those who do. In this respect, the separated scientific disciplinary approach is not appropriate for students who do not continue their education to tertiary level. In other words, the curriculum was designed not for meeting their needs but for students who wants to go to tertiary level of education. It is very unfortunate that the students who are not in this position suffer most from the approach because they should learn something outside their needs.

The existing Senior High School Curriculum structure has two different levels of education,namely, general and academic stream education. General education is for students of Year 10 and they should study all academic disicplines such as mathematics, physics, biology, chemistry, history, geography, economics, sociology, foreign language other than English. In addition, they should also study religion, civics, Indonesian language, English, arts and culture, physical education and sports, information and communication technology. All together there are 16 courses the students of the Year 10 should study. At the end of Year 10, the students will be evaluated and when they are successful to meet promotion criteria the students will be promoted to the Year 11 and to one of the academic streams. The basis for the promotion and streaming is their academic performances in Year $10^{4}$. There are three academic streams they can go for Year 11 and Year 12 which are Language, Science, and Social Studies.

The promotion to one of the academic streams in Year 11 is final and a foundation for Year 12 in a sense that they cannot change or go to another academic stream in Year 12. In each academic stream, the students will learn selected courses related to the major of respective academic stream. For example, students promoted to Language stream will learn the core of the stream which are Indonesian Language, English, and foreign language other than English; for students promoted to Science (IPA) stream they will study mathematics, physics, biology, chemistry as the core courses for the stream; and for students promoted to Social Studies (IPS) stream they will study the core and the compulsory courses such as history, geography, economics, sociology. However, history is compulsory for all students of Year 11 and Year 12 together with religion, bahasa Indonesia (Indoneian language),citizenship education, physical education, English, arts and culture, information technology, local contents courses, and personality development irrespective their academic stream. In Year 11 and Year 12 all

4 In Indonesia educational system there is no automatic promotion. From Year 1 of Primary School up to Year 12 of Senior Secondary School, at the end of every academic year the students will be evaluated and determined whether they are successfully promoted to the next class (Year) or they should repeat the same class in the next academic year. 
students should learn 15 courses and these courses constitute 39 credit hours a week. It means in Year 11 and Year 12 the students learn less number of courses compared to Year 10 which is 18 courses but they have longer period of study because the curriculum allocated 38 credit hours a week for learning those 18 courses.

\section{History Education in The Existing Curriculum}

\section{Reasons for History Education}

The Minister Regulation elaborates justification for history education as follows: History is a discipline which studies ancestors, the development and role of the past society by specific methods and methodology. As far as primary and secondary education are concerned, knowledge of the past is necessary and important as there are a lot of wisdoms and values which are useful for the development of intellectual, attitudes, characters, and personality of students.

As an educational course, history is strategic for the development of characters and civilization of the nation, and for the development of younger generation of Indonesia to be patriotic and nationalistic citizen. The contents of history consist of:

1. Values of heroism, leadership, patriotism, nationalism for the development of characters and personality of the students.

2. Achievements of civilization of Indonesia and other nations. These achievements are fundamental for the development and creation of future Indonesian civilization;

3. Values for national unity, brotherhood, and solidarity which are important for national integrity ;

4. Moral and wisdom teaching which are important for dealing with multidimentional crisis the students confront in their daily lives;

5. Values for the development of responsibility for preserving the environment.

The reasons show that history education is considered important because the content of history are officially recognised as fundamental and effective contents for the development of intellectual skills, moral and characters, and as sources of inspiration for students. The nature of history contents which concerned with the past human achievement, is also a content for developing national identity and characters. Thus, all past experiences are important contents for understanding who we are and why we are so doing to achieve the designated future. By recognizing this pivotal position, the curriculum designed history education as a compulsory course.

\section{Objectives of History Education}

On the same document, the Minister Regulation, it is stated that history education has the following objectives: 
1. To develop the awareness the importance of time and its process which continues from the past, present, and future.

2. To develop critical thinking in understanding historical facts correctly according to scientific criteria and methodology.

3. To develop appreciation to historical artefacts as evidences of the past civilization of the nation,

4. To develop understandings about the process of the nation building through a very long process which still continues to the present and future.

5. To develop awareness, pride, and patriotism as a citizen, and be able to implement those values in national and international lives.

The above objectives of history education clearly indicate that history education aims at the development of students awareness of time concept; scientific knowledge of the society in the past in terms of their values, ways of thinking, attitudes and achievement; skills for understanding and generating knowledge of the past; attitudes towards history as what happened in the past society, and history as a science that reconstruct the past . To put it in a simple way the objectives suggest that students should have knowledge about the past scientifically and this knowledge is gained through the application of historical thinkings and skills. The objectives also suggest that history education should prepare students for their roles as a citizen who loves and is proud of the country, the nation and their past achievement. Further, the objectives place history as an education media for preparing the students for their future lives.

The objectives of history education answers the second question of the present study conceptually because the objectives encompass thinking skills and historical ways of knowing. However, the question on how the curriculum provide the learning opportunities for students to development of those qualities should be analysed from the competencies designed in curriculum. Thus, objectives are the qualities students should have but the curriculum is the plan for learning for students to achieve the qualities. Although theoretically the construction of the plan should be based upon the stated objectives, however, empirical proof on the plan should be conducted.

\section{Position of History Education in the Structure of Curriculum}

As previously mentioned, history is compulsory subject for all students of Year 10, Year 11, and Year 12. However, as far as history contents are concerned there are some differences related to the year and academic stream. In Year 10, all students study the same topics and depth of history for two semesters and one hour for each semester. For students Year 11 and Year 12, the number of credit hours differs according to pedagogical position of history education to the cores of the academic streams. The scope of the history contents for each academic stream are in variance. The difference in scope of the content might have a consequence in time allocation. The following table shows the number of credit hours allocated for Year 10, Year 11 and Year 12 for history education for each stream. 
Table 1.1: Time Allocation for History Education

\begin{tabular}{|c|c|c|c|c|c|c|}
\hline \multirow{3}{*}{ Academic Stream } & \multicolumn{5}{|c|}{ Year and Semester } & \\
\hline & \multicolumn{2}{|c|}{10} & \multicolumn{2}{|c|}{11} & & 12 \\
\hline & 1 & 2 & 1 & 2 & & 2 \\
\hline General & 1 & 1 & - & & & - \\
\hline \begin{tabular}{|l} 
Language \\
\end{tabular} & 1 & 1 & 2 & & & 2 \\
\hline \begin{tabular}{|l|} 
Social Studies \\
\end{tabular} & 1 & 1 & 3 & & & 3 \\
\hline Science & 1 & 1 & 1 & 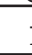 & . & 1 \\
\hline
\end{tabular}

Constructed from Standar Isi, Peraturan Menteri Pendidikan (Minister Regulation) no. 22 tahun 2005

Table 1 shows that time allocation for Year 10 History is one credit hour for every semester. These two semesters of Year 10 can be considered as basic for history education. It is an initial year for students to learn history. This means that what students learn in the first year will be developed further in following years.Time allocation for History Year 11 and Year 12 varies for every academic streams. For Language academic stream, the time for students to study history is two credit hours while for Social Studies studies academic stream is three credit hours, and for Science academic stream is one credit hours.

The time allocation shown on Table 1 is decided by Minister of National Education Regulation number 22 year 2005 on Content Standard. It indicates the views of curriculum decision makers about the position of history education and on the perceived needs of the each academic stream. Nevertheless, the perceived needs of each academic stream does not mark the degree of importance of history education but it is an indication of its relevancy to the study history for that particular academic stream. By that point of view it is decided scope of historical contents for each semester of respective academic stream and corollary its time allocation. As shown on Table 1 time allocation for Year 10 is the same with Year 11 dan Year 12 of Science stream. For Social Studies stream where students should learn more historical events than other academic streams, so it very natural that time allocated for Social Studies stream is the highest. Albeit the difference in the number of historical topics, the difference in time allocation for each academic stream the curriculum requires teachers to implement different but complementary strategies of teaching. This means teachers of history of Year 10, Year 11, and Year12 should work together in planning the teaching of history as such so the principle of continuation, complementary, and linked to each other can be designed from the outset of academic year.

Nevertheless, the distribution of the credit semester for history education shows that in every semester there is time allocated for history. This means that every student learns history from beginning of the academic year until Year 12, the last year of senior secondary school curriculum. While the number of credit hours is an indicator of relevancy, the scope and the amount of works the existence of the course in every semester is an indicator of the importance of the course. 
By the fact that the existing curriculum offers history in every semester it can be concluded that history is an important academic subject in the curriculum.

\section{Scope and Organization of History Content}

As the credit hour for each stream varies, naturally, the scope of the content of history for respective academic stream also varies. Curriculum wise, time allocation is an indicator which reflects the variation of the scope and the way to organise the content. The following table shows data which support the view that time allocation does indicate the variation in scope of content and the depth of the content. The following table is constructed from "Competency Standards" (Standar Kompetensi) and "Basic Competency" (Kompetensi Dasar) as stated in the Ministry Regulation number 22 Year 2005 .

Table 1.2: Content Standard for History Teaching for the Academic Streams

\begin{tabular}{|c|c|c|c|}
\hline \multirow{2}{*}{$\begin{array}{l}\text { Grade and } \\
\text { Semester }\end{array}$} & \multicolumn{3}{|c|}{ Academic Streams } \\
\hline & Social Studies & Language & Science \\
\hline $\begin{array}{l}\mathrm{X} \\
\text { Semester } 1\end{array}$ & $\begin{array}{l}\text { To understand basic } \\
\text { concepts of history }\end{array}$ & $\begin{array}{l}\text { To understand basic } \\
\text { concepts of history }\end{array}$ & $\begin{array}{l}\text { To understand basic } \\
\text { concepts of history }\end{array}$ \\
\hline Semester 2 & $\begin{array}{l}\text { To analyse Indonesia } \\
\text { and World civilization }\end{array}$ & $\begin{array}{l}\text { To analyse Indonesia } \\
\text { and World } \\
\text { civilization }\end{array}$ & $\begin{array}{l}\text { To analyse Indonesia } \\
\text { and World } \\
\text { civilization }\end{array}$ \\
\hline $\begin{array}{l}\mathrm{XI} \\
\text { Semester } 1\end{array}$ & $\begin{array}{l}\text { To analyse the } \\
\text { development of } \\
\text { Indonesian traditional } \\
\text { kingdoms }\end{array}$ & $\begin{array}{l}\text { To analyse the } \\
\text { development } \\
\text { of Indonesian } \\
\text { traditional kingdoms }\end{array}$ & $\begin{array}{l}\text { To analyse the } \\
\text { development } \\
\text { of Indonesian } \\
\text { lives in the time } \\
\text { of traditional } \\
\text { kingdoms, colonial, } \\
\text { national movement, } \\
\text { and Proclamation of } \\
\text { Independence }\end{array}$ \\
\hline Semester 2 & $\begin{array}{l}\text { To analyse the } \\
\text { development of } \\
\text { Indonesian lives from } \\
\text { the beginning of the } \\
\text { western influences up } \\
\text { to Japanese occupation }\end{array}$ & $\begin{array}{l}\text { To analyse the } \\
\text { development of } \\
\text { Indonesian lives } \\
\text { during the period of } \\
\text { colonial time and the } \\
\text { beginning of national } \\
\text { movement }\end{array}$ & $\begin{array}{l}\text { To reconstruct } \\
\text { the development } \\
\text { of Indonesian } \\
\text { nation since the } \\
\text { Proclamation of } \\
\text { Independence up } \\
\text { to the beginning of } \\
\text { New Order }\end{array}$ \\
\hline & $\begin{array}{l}\text { To analyse some world } \\
\text { history events which } \\
\text { influence the lives of } \\
\text { Indonesian from } 18 \text { to } \\
20 \text { centuries }\end{array}$ & - & - \\
\hline
\end{tabular}


HISTORIA:

International Journal of History Education, Vol. XI, No. 2 (December 2010)

\begin{tabular}{|c|c|c|c|}
\hline \multirow[t]{2}{*}{$\begin{array}{l}\text { XII } \\
\text { Semester } 1\end{array}$} & $\begin{array}{l}\text { To analyse the } \\
\text { development of } \\
\text { Indonesian nation } \\
\text { from the Proclamation } \\
\text { of Independence to } \\
\text { the emergence of New } \\
\text { Order }\end{array}$ & $\begin{array}{l}\text { To reconstruct } \\
\text { the development } \\
\text { of Indonesian } \\
\text { nation since the } \\
\text { Proclamation of } \\
\text { Independence to the } \\
\text { emergence of New } \\
\text { Order }\end{array}$ & $\begin{array}{l}\text { To reconstruct the } \\
\text { development of } \\
\text { Indonesian nation } \\
\text { from the New Order } \\
\text { to the period of } \\
\text { Reformation }\end{array}$ \\
\hline & $\begin{array}{l}\text { To analyse the } \\
\text { development of } \\
\text { Indonesian nation } \\
\text { from the period of New } \\
\text { Order to the period of } \\
\text { Reformation }\end{array}$ & |- & - \\
\hline Semester 2 & $\begin{array}{l}\text { To analyse the world } \\
\text { historical events from } \\
\text { World War II to the } \\
\text { recent development }\end{array}$ & $\begin{array}{l}\text { To reconstruct the } \\
\text { development of } \\
\text { Indonesian nation } \\
\text { from the period } \\
\text { of New Order } \\
\text { to the period of } \\
\text { Reformation }\end{array}$ & $\begin{array}{l}\text { To analyse the } \\
\text { development } \\
\text { of science and } \\
\text { technology in the } \\
\text { 2oth century }\end{array}$ \\
\hline
\end{tabular}

Constructed and translated from Standar Isi, Permen nomor 22 tahun 2005

As shown on Table 2 the scope of the contents of history education is from the earliest period of the lives of Indonesian ancestors up to recent development, Reformation period. For the Social Studies stream the content covers also world history while for the Science stream the content also covers the development of science and technology. World history is exclusive content for Social Studies stream as does history of science and technology for Science stream. For Social Studies stream world history is designed for Year 11 semester 2 exclusively on world history events that are related and might affect Indonesian history and Year 12 semester 2 on world history events unnecessarily related to Indonesian history.

Table 2 also shows different scope of the content for each semester of those academic streams. In the first semester Year 11 the scope of history contents for Social Studies and Language streams is the same which is Indonesian traditional kingdoms. Take into consideration about the amount of time allocated for Social Studies is three credit hours and for Language is two credit hours, it is obvious that the same scope in terms of period does not lead to the same number of topics of traditional kingdoms. Furthermore, to take into consideration the time allocation and the scope of the content, it is only natural that students of Social Science stream explore more depth than students of Language stream. In other words, they have more history educational material to learn than the students of Language stream. 
Scope of the content for the first semester of Year 11 Science stream is very much broader than the one for Social Studies and Language streams. It covers nearly the whole periods of Indonesian history, namely, from traditional kingdoms, national movement, colonial period up to proclamation of Indonesia independence. Considering the fact that students should learn that vast scope in one credit hour (50 minutes) a week than it can be imagined that the learning can only deal with historical fact if the teaching is delivered in a traditional way. It could hardly be possible that the students to analyse, evaluate, or reconstruct the whole lot of historical events for that vast periods. In other words, teachers of history for those classes should apply new and innovative approaches such as project-based learning where every student is assigned to study a particular historical event of her/his choice for in a particular semester.

Unlike the pattern of the scope in the first semester where Social Studies and Language streams have the same scope, in the second semester of Year 11 the scope of the content for these two the academic stream varies. For Social Studies stream, the scope starts from the coming of western influence up to Japanese occupation, and some world history events in the period of 18 to 20 centuries. For the Language stream, the scope is from the coming of western colonial influence up to the awakening of national movement. For the Science stream, the scope is from proclamation of Indonesia independence up to the New Order.

The same pattern of the second semester Year 11 is applied to the scope of the first semester Year 12. The scope for Social Studies and Language starts at the same period, namely, the proclamation but as the scope for Social Studies goes to the period of Reformation, the scope for Language ends at the period of the New Order. The period of the New Order up to Reformation is the scope of the second semester (the last semester) for Language stream. For Science stream, the period of the New Order up to Reformation is the scope of the first semester Year 12. The period of Reformation is the last period for the scope of Indonesian history.

In the second semester Year 12, the scope of history education for Social Studies stream is exclusively on world history while for Language stream is from New Order up to Reformation, and for Science stream is on the development of science and technolgy in 2oth century. So in the last semester Year 11 and Year 12 of the Senior Secondary School Curriculum, the scope of history education for those three academic streams varies significantly. To put things altogether, the differences of the scope of history education amongst those three academic streams affects the depth of the contents, and there are additional topics of world history for Social Studies, and history of science and technology for Science.

Another information Table 2 shows is on historical skills the students should perform. The skills are competencies indicated by the verb used in the sentences of competency standards. For students of Social Studies stream they should develop analysis skills. For students of Language and Science, they should develop analysis skills and reconstruct skills of historical event. Needless to say that the ability to reconstruct is higher than analysis skills. The question 
is why the students of Social Studies stream should develop only analysis skill while history is one of core courses for that academic stream while students of other academic streams should develop the skills up to recostruct. For history education, to reconstruct an historical acount is the highest level of cognitive because it is at the level "to create" in the revised version of cognitive domain (Anderson, 2001). Logically, the students of Social Studies should develop the more rigorous skills of history than students of Language and Science streams. Moreover, the competency to reconstruct needs more time to develop and require analysis and evaluation skills and naturally these skills Social Studies students need to develop. It is hard to argue that the meaning of analysis for Social Studies stream is different from Language and Science because this term is used by the same curriculum of senior high school curriculum. Therefore, this finding shows that there is a problem, and a significant one, for the development of historical thinking and skills as planned in the curriculum.

In short, it can be summarised that the existing curriculum provides opportunities for all students to learn and develop historical thinking and historical skills in the first semester. In this first semester, students learn basic concepts of history as an area of inquiry and basic skills of historical research. In the following semesters the historical thinking and historical skills the students have learned should be applied in the study of historical events in the second semester and following semesters. Thus, the organization of the content of history education shows that the first year is the foundation year for the development of historical thinking and historical skills and the other five following semesters are designed for fortified and enrich them.

\section{Discussion}

Two questions were addressed in the present study (1) what is the concept of history education as it is stipulated in curriculum document?, and (2) how far the existing curriculum provides possibilities for the development of historical thinking and skills? To answer the first question of the concept of historical education, the first three objectives of history education clearly indicate that history education in the existing curriculum is based upon the philosophy of essentialism. This philosophy aims at the development of intellectual powers. Tanner and Tanner (1980:109) wrote that "the concern with personal problems of adolescents has grown so excessive as to push into the background what should be the school's central concern, the intellectual development of its students".This means that history education should pay its mainly concern to the development of intellectual skills. The first three objectives are undoubtedly very much represent the idea of essentialism which are (1) to develop the awareness the importance of time and its process which continues from the past, present, and future, (2) to develop critical thinking in understanding historical facts correctly according 
to scientific criteria and methodology, (3) to develop appreciation to historical artefacts as evidences of the past civilization of the nation. The cultivation of intellectual and rational ability and the transmission of cultural heritage are essentialism-based objectives.

This position is further supported in the curriculum by putting history as a course in the category of science and technology which aims at "master competencies at advanced level of knowledge in the field of science and technology and to cultivate the habit of critical, creative, and independent scientific thinking" (Minister Regulation number 22, 2005). Again the aims of this science and technology category is fundamentally based-on the essentialism point of view. Also, the label of history for the course is very much indication of the application of the philosophy (Tanner and Tanner, 1980:9). In other words, as far as history education is concerned, the existing curriculum structure has placed essentialism as the philosophical foundation of history education. This means in the existing curriculum, history education is conceptualised as the teaching of academic discipline.

Philosophy of essentialism views the aim of education is to cultivate intellectual ability (Tanner and Tanner, 1980; Longstreet and Shane, 1993; Oliva, 1997). It is also the basic belief of essentialism that education aims at the transmission and preserving cultural heritage (Longstreet and Shane, 1993; Oliva, 1997) where it deprecates modern studies and "rejects social sciences in favor of history". In short, it can be concluded that in the existing curriculum history education is defined as a teaching of discipline because history has a wide range of knowledge on cultural heritage, the capacity to transmit them to young generation, and used the glory past to cultivate rational and intellectual power of students. Although the notion that the past is "a bank of examples or contemplating present problems has come under challenges" (Wineburg, 2001:11) because the past is considered no longer existing in the present lives, the fact is that kind of claim is not entirely true.

Considering the aims of senior secondary school to prepare students for their tertiary education then the use of the philosophy of essentialism for history education does supports the instutional mission. This means that the curriculum designs that students of senior secondary school, especially students of Social Studies stream are interested in history and will continue their tertiary education to history department or school. When a lot of students of Social Studies stream go to history departments of many universities then this point of view of the curriculum design is justified. Otherwise, the curriculum design should be reviewed and the position of history education as a teaching of academic discipline must be discussed thoroughly.

A further analysis of the objectives of history education reveals that to put history education in the circle of essentialism is not exclusive. The objectives of history education also show that history education should also be concerned with the need of society and the nation. As stipulated in the document, history education is also directed towards citizenship education. Citizenship education is not only 
to prepare students as a member of society but it is more on the preparation of the students to be active and productive citizens. As explicitly stated in objectives of history education (4) to develop understandings about the process of the nation building through a very long process which still continues to the present and future, and (5) to develop awareness, pride, and patriotism as a citizen, and be able to implement those values in national and international lives. In other words, the students are educated to be "agents of change" for their lives in the present and future society. It is the philosophy of progressivism and reconstructionism which uses school "to achieve what they considered to be improvements in society" (Oliva, 1997:178) and "the organization and the behaviour of groups". This both philosophies are stated clearly in the objective of history education and as the progressivism is concerned with present but reconstructivism is concerned with future and the last two objectives of history education are concerned with the two dimensions of human lives. The bank of examples in history is a very sound ground not only to understand the present but also to serve as a bank for acting, behaving, changing the present and to "charter the future" (Wineburg, 2001).

To answer the second question can be discussed using data on the design of the contents as shown on Table 2. As stated in the competency standard of the first semester all students learn about historical thinking and skills. Then, there is no information about the connection between the thinking and skills and the following 5 semesters. It is assumed that the thinking and skills students learn in the first semester are further developed and improved in the following semesters. If this assumption holds true then consecutive design of thinking and skills development is used by the curriculum. This consecutive design is depicted in the following diagram.

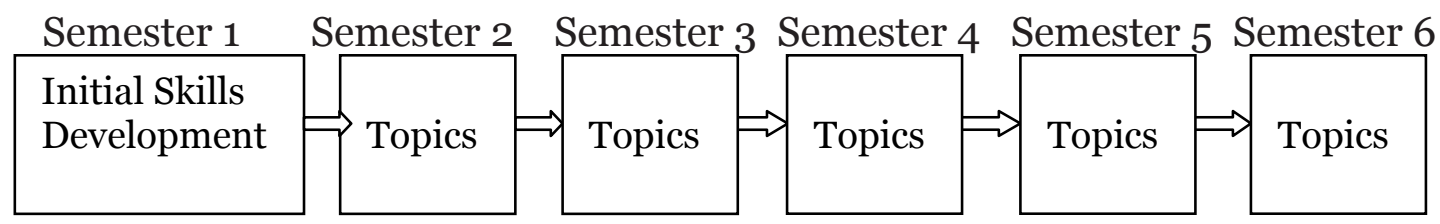

Diagram 1: Consecutive Design For Skill Development

This design is very appropriate when the number of topics and time allocated for each stream are different so the design suits the model of the existing curriculum. By this design the development of historical thinking and skills in the first semester Year 10 provides students with the same opportunity to have initial experiences to develop the two qualities. When the students go to the second semester they have learned already learn the skills and they are already in a position to implement the historical thinking and skills to study all topics. In other words, when the students in the second semester and so on, they can develop further their historical thinking and skills. Teachers can plan the further development of the two kinds of skills by using inquiry, problem solving, projectbased learning or even the usual and everyday way of teaching. 
This approach should be used in syllabuses. In the syllabus of the first semester teachers should plan to select and implement all available approaches of effective learning for skill development. Also, the focus should be on the understanding of the meaning of the skills and exercises to develop them. Individual or group works can be one of the learning approach used in the first semester. Cooperative learning can be an appealing alternative for the group work. In the next semesters students learn historical stories stipulated in the respective semester.

So, syllabus for the first semester is different from other semesters in many ways. In the first semester students should study skills rather than knowledge. However, as the skills can only be learned and developed through the study of history events, teachers should decide what topics the students will learn. The selection can be conducted from topics in the subequent semesters or teachers can select topic(s) from outside the semesters. By doing the latter, of course, the students learn more topics than stated in the curriculum. By doing the first students do not learn more topics as already mentioned in the curriculum. Whatever approach is selected in the development of syllabuses the students can also have an ample opportunities to do depth study on particular topics.

Teachers can provide learning experiences for the depth study in two ways, individually or in a group. Individually, a student can select a particular topic of interest for the depth study and the student should submit a paper at the end of a particular semester or a particular year. The selected topics for this approach are necessary to confine to a semester where the student is in. Basically, group approach is the same with an individual approach because the difference is only on one individual student or a number of students who does the depth study.

The consecutive design has a fundamental drawback, namely, the limited time for the development of the historical thinking and skills. A semester is a very short time and teachers and students shoould work really hard to master the historical thinking and the skills. As already noted in the discussion of content section, the development of skills always requires much longer time compared to the mastery of knowledge. It is unavoidable no matter what learning and teaching method is used. Therefore, the consecutive model with one credit hour might cause a lot of problems for the development and mastery of the two skills at the necessary or accepted level. A very profound and delicated assessment techniques is necessary to get valid information about the success and problems the students have in mastering the skills in the first semester followed by necessary remedial teaching.

Another design to develop the skills is to develop them at the same time the students learn knowledge or substantive content in an integrated design. By this design both contents, knowledge and skills, and even values are organised along the six semesters. There is no specific or exclusive semester to develop and master the skills as in the consecutive design. In other words, students and teacher have six semesters to develop the skills every time they study an historical account. The following diagram shows the design: 


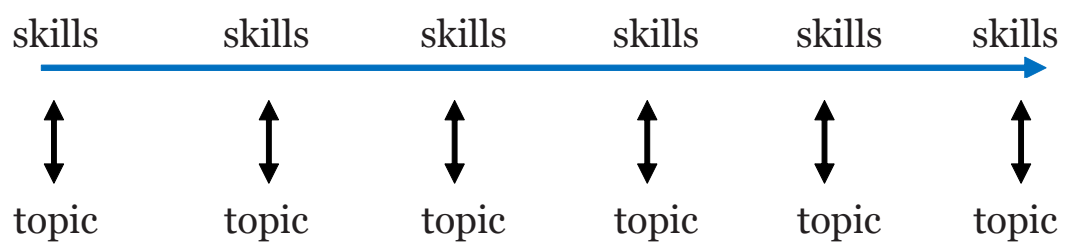

Diagram 2: Integrated Design for Skills Development

As shown in Diagram 2, there is a continuation across the semesters for the development of historical thinking and skills. Knowledge content in every historical topic in a semester is used for the development of the skills. By this design, teachers have an ample of time for the development and liberty to plan the level of mastery of the skills in every semester. Teachers have liberty to decide whether all those skills will be developed every time students learn a topic or might plan to develop particular historical thinking and skills for particular topics. Also, teachers is in position to decide in what semester all those skills are already mastered and ready to use in the next semester(s).

Similar condition to consecutive model is also applied to integrated model, namely, teachers should plan the syllabus for the whole years. This means that when a new academic year starts syllabuses for Year 10, 11, and 12 are already planned. When a teacher of history of Year 10 is different from teachers of Year 11 and 12, then it is an obligation they should develop the syllabuses together at the outset of an academic year as such so the link and continuity for the development of the skills are secured in a sound and meaningful way. The coopertive work amongst teachers of history is critical as it can affect the success of history education.

\section{Conclusions}

From the findings and discussion of the findings, it can concluded that history education is conceived as academic discipline education. Despite some difficulties for students who do not continue their study to university and choose history as their majors, the position of history education for senior secondary education is appropriate to serve the aims of senior secondary school. In future, some thoughts and curriculum decision for history education for students who do not choose history as their majors and those who do not go to university should be decided.

Secondly, the existing curriculum provides ample opportunities for teachers to develop historical thinking and skills. While these two kinds of skills should not be developed separatedly, the existing curriculum applies consecutive design for the development of historical thinking and skills. This design put a lot of pressure on teachers and students for learning and mastering the two skills in one semester. An alternative is suggested which is integrated design where teachers have more liberty in planning. 


\section{REFERENCES}

Anderson, et al. (2001). A Taxonomy for Learning, Teaching, and Assessing. New York: Longman

Jakubowski,C.T.(2002). Teaching World History: Problems and Promises Faced by Young Teachers. World History Bulletin. XVIII, 2.

Bloom, B.S. (ed.) (1956). Taxonomy of Educational Objectives. Book 1 Cognitive Domain. Ann Arbor, Michigan: David McKay Company, Inc

Borries, Bodo von (2000). Methods and Aims of Teaching History in Europe: A Report on Youth and History, dalam Knowing Teaching \& Learning History: National and International Perspectives (Eds. Stearns, P.N., Seixas,P., Wineburg,S.). New York: New York University Press.

California State Board of Education (2000).History-Social Science Content Standards for California Public Schools: Kindergarten through Grade Twelve. Sacramento: California Department of Education

Deb, S. (2003). Textbook Troubles. Available at http://www.countercurrents.org

Drake, F.D. dan Nelson,L.R. (2005). Engagement in Teaching History: Theory and Practicess for Middle and Secondary Teachers. Columbus, Ohio: Pearson Merril Prentice-Hall

Fullan, M. and Pomfret, A. (1971). Research on Curriculum and Instruction Implementation. Review of Educational Research, 47, 2: 335-397

Gardner, H. (1999). The Disciplined Mind: What Students Should Understand. New York: Simon and Schuster

Giese, J.R. (1996). Studying and Teaching History, dalam Teaching the Social Sciences and History in Secondary Schools: A Methods Book. Long Grove, Illinois: Waveland Press, Inc.

Gordon, B. (2003). Intelligent Memory: A Prescription for Improving Your Memory" New York: Penguin Books.

Hasan,S.H. (2003). Strategi Pembelajaran Sejarah Pada Era Otonomi Daerah Sebagai Implementasi Kurikulum Berbasis Kompetensi. Makalah

Hasan, S.H.(2008). Pengembangankompetensiberfikirkritisdalam pembelajaran sejarah. Makalah

Harris, R. (2001) Introduction to Critical Thinking http://www.virtualsalt.com/ think/introct.htm (January 1, 2001)

Hess, F.M. (1999). Bringing the Social Sciences Alive: 10 Simulations for History, Economics, Government, and Geography. Boston: Allyn and Bacon.

Hursh,D.W. dan E.W. Ross (2000). Democratic Social Education: Social Studies for Social Change. New York: Palmer Press.

Koblin, D. (1996). Beyond the Textbook: teaching history using documents and primary sources. Portsmouth, NH: Heinemann.

Levstik,L.S. (2000). Articulating the Silences: Teachers' and Adolescents' Conceptions of Historical Significance, dalam Knowing Teaching and Learning History: National and International Perspectives, Knowing Teaching and 
Learning History: National and International Perspectives, ed. Stearns,P.N., P. Seixas, dan S. Wineburg.

Lindquist,T. (1995). Seeing the whole through social studies. London: Heinemann

Longsreet, W.S. dan Shane, H.G. (1993). Curriculum for a New Millenium. Needham Heights, MA: Allyn \& Bacon

Mansilla, V.B. dan Gardner, H. (2008). Disciplining the Mind, Educational Leadership, vol. 65, no. 5, Februari 2008, hal. 14-19

Ministry of Education (?). Social Studies in the New Zealand Curriculum. Wellington: Learning Media.

Mrdalj,S and Jovanovic, V. (2003). Advancing the System Analysis and Desiign Curriculum.

NCSS (1994). Curriculum standards for social studies: expectations of excellence. Washington,D.C.: NCSS

Nebraska, State Board of Education (1998). Nebraska Social Studies/History Standards: Grades K-12. [Online]. Tersedia: http://www.nde.state.ne.us/SS/ SocSStnd.html. (25 Mei 2001).

New York State Department of Education (1996). Learning Standards for Social Studies. Albany: The State Department of Education

NIER (1999). An International Comparative Study of School Curriculum. Tokyo: National Institute for Educational Research.

North Carolina State Board of Education (2004). North Carolina Standard Course of Study. Available at http://www.ncpublicschools.org/curriculum/foreword

O'Donnell, S., et al.(2002). International Review of Curriculum and Assessment Frameworks. Comparative Tables and Factual Summaries-2002. London: National Foundation for Educational Research

Oliva, P.F. (1997). Developing the Curriculum, $4^{\text {th }}$ ed., New York: Longman

Tanner, D. dan Tanner, L.N. (1980). Curriculum Development: Theory into Practice. New York: Macmillan Publishing Co., Inc.

Tanriverdi, B. and APAK, O (2010). Analysis of Primary School Curriculum of Turkey, Finland, and Ireland in Terms of Media Literacy Education. Available at http://www.faqs.org/periodicals/201004/2040416911. html\#ixzz1AjU31Kqk. Januari 2011

Wineburg, S. (2000). Making Histrotical Sense, dalam Knowing Teaching and Learning History: NationalandInternationalPerspectives(Eds. Stearns,P.N., Seixas, P. dan Wineburg, S.). New York: New York University Press

Wineburg, S. (2001). Historical Thinking and Other Unnatural Acts: Charting the Future of Teaching the Past. Philadelphia: Temple University Press

Document

Peraturan Menteri Pendidikan Nasional nomor 22 tahun 2005 tentang Standar Isi 